УДК 631.4

DOI 10.18101/2587-7143-2019-1-13-21

\title{
ГАЛОГЕНЕЗ ПОЧВ ПРИОЛЬХОНЬЯ И О. ОЛЬХОН
}

\author{
Н. А. Зверева, Е. Р. Хадеева
}

(C) Зверева Надежда Анатольевна

Ведущий инженер

Институт географии им. В.Б. Сочавы СО РАН,

Россия, 664033, Иркутская область, г. Иркутск, ул. Улан-Баторская, 1

E-mail: kofffein@mail.ru,

\section{(C) Хадеева Екатерина Романовна}

Ведущий инженер

Институт географии им. В.Б. Сочавы СО РАН,

Россия, 664033, Иркутская область, г. Иркутск, ул. Улан-Баторская, 1

E-mail:war_ker@mail.ru

В Приольхонье и на о. Ольхон, в прибрежной части соленых озер, формируются интразональные почвы - солончаки, содержащие в профиле легкорастворимые соли в количествах токсичных для растений. Солончаки и другие засоленные почвы являются интересным объектом для исследования в плане классификации, влияния криогенных и других факторов формирования, а также галогенеза. Одним из факторов галогенеза является пульсация озер и накопление солей при испарении капиллярных растворов грунтовых вод на поверхности почвы. В результате аридизации климата, соленые озера высыхают и за счет этого увеличиваются площади засоленных почв. Процесс галогенеза и причина солевых аккумуляций до сих пор не находят единство взглядов в связи с недостаточным вниманием к геосистемному подходу.

Ключевые слова: аридизация климата, галогенез, засоленные почвы, карстовые озера, о. Ольхон, озера тектонического происхождения, Приольхонье, токсичные соли.

\section{Для цитирования:}

Зверева Н. А., Хадеева Е. Р. Галогенез почв Приольхонья и о. Ольхон // Вестник Бурятского государственного университета. Биология, география. 2019. № 1. C. 13-21.

В Тажеранской степи Приольхонья и на о. Ольхон распространены реликтовые минеральные бессточные озера в контурах мезо-кайнозойских «пулл-апарт» структурах тектонического образования, которые определяют режим питания озер (Склярова, 2004). На химический состав вод озер оказывает влияние процесса эвапоритизации. Вследствие уменьшения зеркала воды происходит концентрация и осаждение солей, и изменение компонентного состава почв береговой линии (Дзюба и др., 2003).

В последнее десятилетие отмечается уменьшение площадей зеркала озер и увеличение площадей засоленных почв. На поверхности этих территорий 
аккумулируются соли, переносящиеся в процессе импульверизации на значительные расстояния (Максимова и др., 2017).

Немногочисленные сведения о засоленных почвах определили цель работы - изучить их физико-химические свойства и дать классификацию по степени засоления.

Объекты и методы. Район исследования находится в горно-котловинной провинции Приольхонья и низкогорного округа о. Ольхон (рис. 1). Рельеф региона характеризуется значительной расчлененностью при относительно небольших колебаниях высот и выражен ярусностью (Лопатин, Сковитина, 2008).
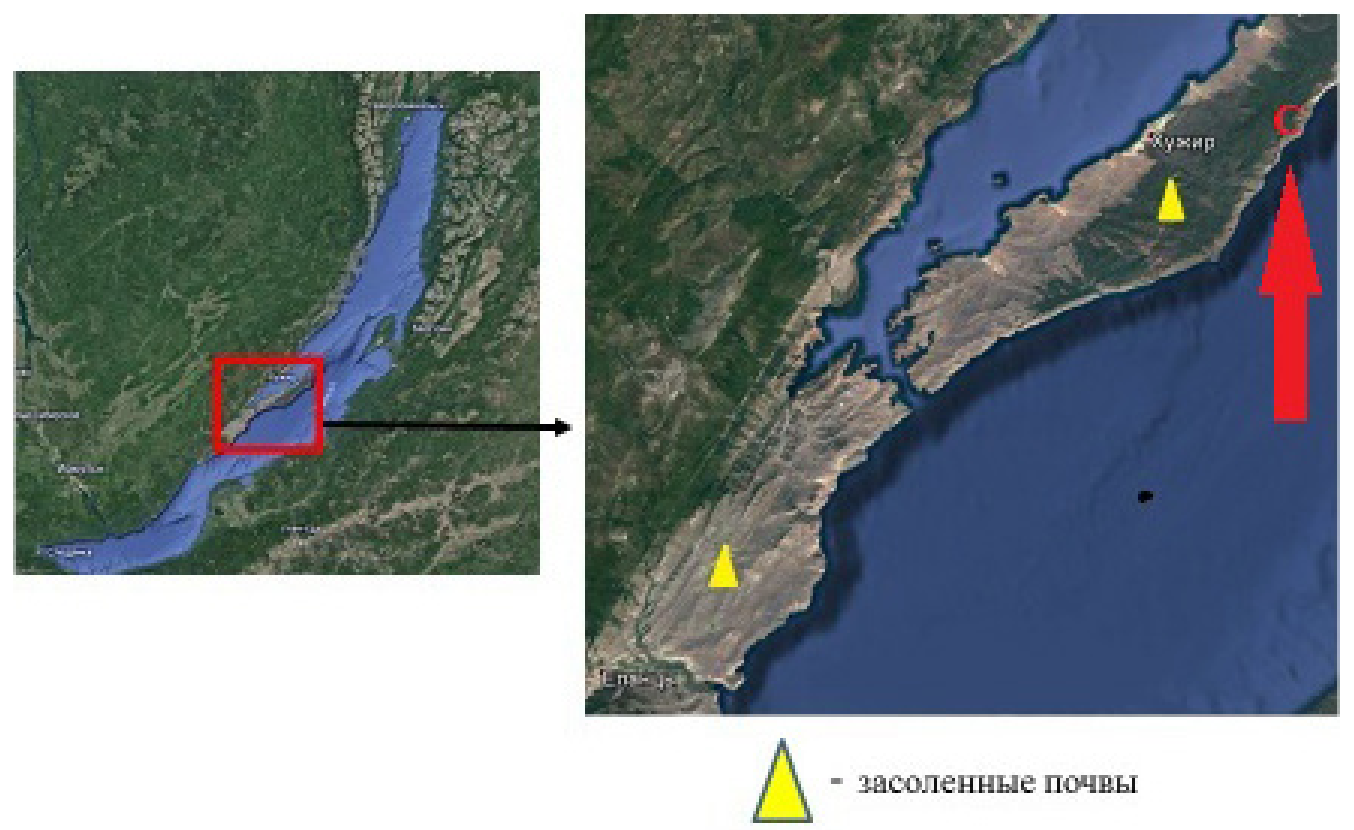

Рис. 1. Районы исследования засоленных почв

На большей части Приольхонья почвообразующие породы представлены элювиально-делювиальными пролювиальными продуктами выветривания кристаллических пород, особенностью которых является маломощность, грубость механического и пестрота петрографического составов, вызванных неоднородностью коренных отложений и их сильной дислокацией. На о. Ольхон почвообразующие породы представлены в основном продуктами выветривания метаморфических и изверженных пород: граниты, диориты, кварц-порфириты, фрагментарно - пестрые кайнозойские отложения, сложенные зелеными озерными глинами и светло-серыми песками (Максимова и др., 2017; Мартынов, 1965).

Климат региона отличается недостаточным атмосферным увлажнением, высокой солнечной активностью, частыми ветрами. Растительный покров Приольхонья очень разнообразен, флористический состав степных сообществ представляют в основном типчаково-тонконоговые, мятликово-типчаковые, вострецово-типчаковые, ковыльно-житняковые сообщества. На выходах коренных пород встречаются типчаково-тимьяновые степные группировки, а в межгривных 
понижениях и по днищам падей - комплексы полынно-типчаково-вострецовых и ковыльно-житняковых степей, заросли чия блестящего, участки галофитных степей. Особое эколого-ценотическое положение занимает растительность подвижных песков о. Ольхон, где господствуют псаммофиты (Атлас Байкала, 1993; Атлас. Иркутская область..., 2004).

Почвенный покров района характеризуется большим разнообразием, как по составу почв, так и по особенностям их строения. На территории исследования выделяются следующие типы почв: горные мерзлотные таежные, горно-тундровые, горные подзолистые, горные дерновые лесные, дерново-слабоподзолистые, дерново-карбонатные, дерновые лесные железистые, луговые, лугово-болотные, каштановые и солончаки (Почвенная карта, 1988).

Объектом детального изучения послужили засоленные почвы около высыхающих озер Приольхонья (от окрестностей пос. Еланцы до пос. Черноруд) и на о. Ольхон (рис. 1).

Озеро Гизги-Нур занимает самое северное положение в цепочке озер, расположено в пади Борсойский Тажеран (рис. 2).

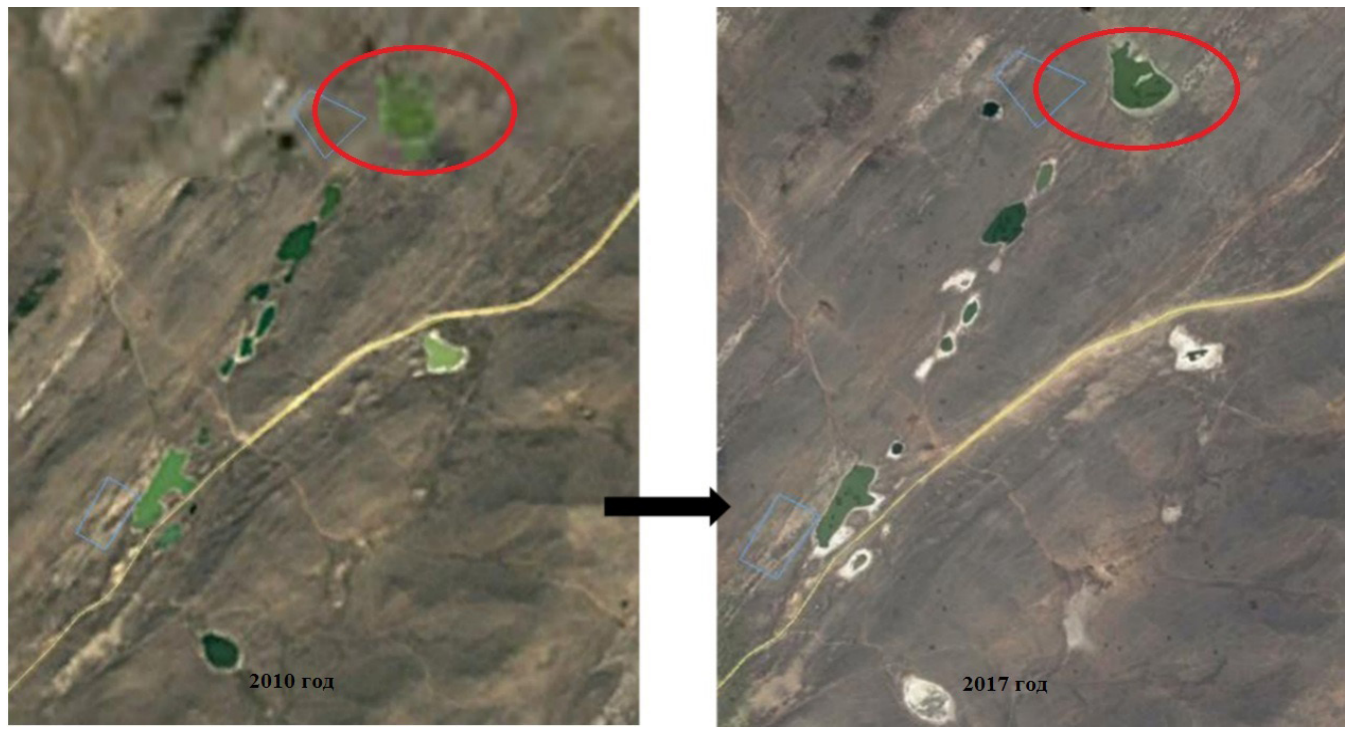

Рис. 2. Изменение береговой линии Тажеранских озер за периоды 2010 - 2017 гг.

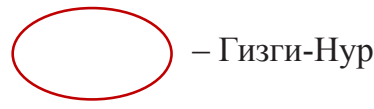

В озёрной депрессии, имеющей ровную поверхность, распространены солончаковые почвы с выраженным карбонатным горизонтом. Другой вид солонцов - солончаковатые солонцы (влажные солонцы), встречаются по краям озёрных впадин и микропонижениях.

Озеро Гизги-Нур в Приольхонье имеет тектонические происхождение. В результате высыхания около озера сформировались засоленные почвы, ставшие объектом нашего исследования. 


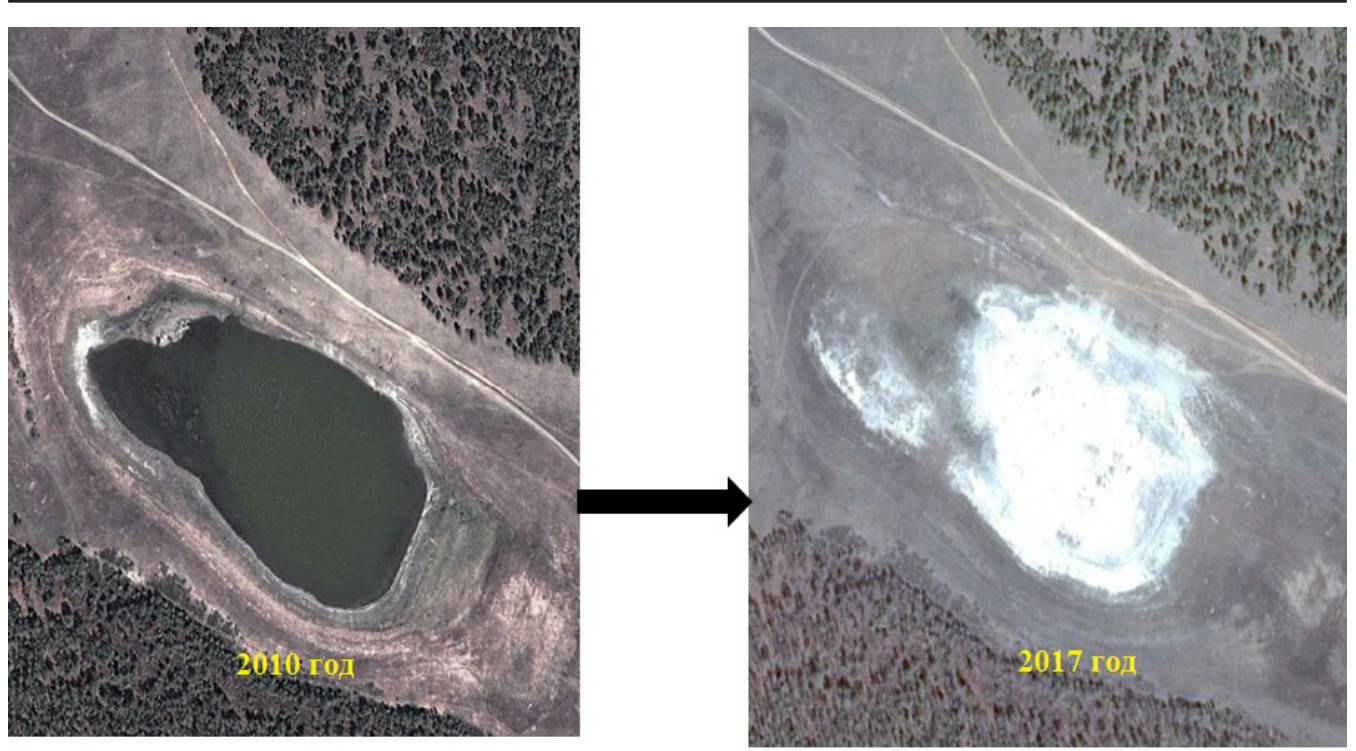

Рис. 3. Изменение площади озера Шара-Нур (о. Ольхон) за 2010 - 2017 гг.

Вопросу образования засоленных почв Приольхонья и о. Ольхон посвящены работы В.П. Мартынова, И.В. Николаева, О.Г. Лопатовской и др. (Мартынов, 1965; Николаев, 1949; Лопатовская. 2018; Черноусенко и др., 2006).

Почвенно-геохимический метод (метод линейной катены) позволил изучить химические процессы почвообразования во времени и пространстве, воссоздавая картину движения, дифференциации и аккумуляции продуктов почвообразования в ландшафтах. Морфологический метод, принятый в почвоведении, явился эффективным способом познания свойств почвы по внешним признакам: окраске, структуре, сложению, новообразованиям, глубине и последовательности залегания горизонтов. Лабораторно-экспериментальный метод позволил охарактеризовать физические и химические свойства почв (Агрофизические... , 1966; Агрохимические... , 1975; Аринушкина, 1970; Воробьева, 2006).

Математические методы включают статистическую обработку данных результатов анализов с использованием программы EXCEL.

Результаты и обсуждение. Результаты физико-химических исследований засоленных почв позволили выявить закономерности в свойствах почв, а также особенности физико-химического состава. В процессе исследования были заложены 2 катены: катена № 1 была заложена около оз. Гизги-Нур (Приольхонье); катена № $2-$ у оз. Шара-Нур (о. Ольхон).

Катена № 1 представлена 3 разрезами, заложенными от вершины приозерной возвышенности до самого уреза оз. Гизги-Нур.

Разрез № 1 (ГН-1) заложен на вершине приозерной возвышенности. В гранулометрическом составе преобладает фракция крупной пыли, которая увеличивается от 38 \% до 61 \% с глубиной. Верхний горизонт представлен легким суглинком, который в нижнем горизонте $(50-60$ см) сменяется на тяжелый суглинок. Реакция среды увеличивается вниз по профилю от 7,5 до 8,8 ед. $\mathrm{pH}$. Степень 
солонцеватости увеличивается с глубины 40 см и к 60 см достигает 9,7\%, при этом отслеживается резкий скачок карбонатов до 2,9 \%. Слабое засоление наблюдается только в нижнем слое. Тип почвы: $A J-B M K-C A T$, ствол - постлитогенные, отдел - аккумулятивно-карбонатные малогумусовые, тип - каштановая типичная.

Разрез № 2 (ГН-2) заложен на средней части склона. В профиле преобладают фракции крупной пыли $35 \%$ и 19 - 24 \% крупного песка в первых 40 см профиля. В нижнем горизонте (40 - 70 см) содержание их выравнивается и составляет по $30 \%$. По гранулометрическому составу почва относится к супеси. Кислотность почвы увеличивается от 7,5 до 8,8 ед. рН вниз по профилю. Возрастает содержание карбонатов от $0,3 \%$ в верхней части профиля, а на глубине $50-60$ см их количество составляет $1,5 \%$. Наблюдается резкий скачок степени солонцеватости до $6 \%$ с глубины 20 см, где выявлено слабое засоление. Тип почвы: $A J-B M K-C A T$, отдел аккумулятивно-карбонатные малогумусовые, тип - каштановая типичная.

Разрез № 3 (ГН-3) - берег озера. Профиль по гранулометрическому составу неоднородный, верхний горизонт представлен средним суглинком, в нижних горизонтах идет облегчение до супеси. Сильнощелочная реакция среды 10,0 ед. $\mathrm{pH}$ снижается к нижнему горизонту до 8,0. Верхние 10 см по степени засоления определены как солончак с содовым типом засоления. Сумма токсичных солей практически полностью доминирует над нетоксичными и составляет $2,5 \%$ от массы почвы (таблица). Ниже по профилю содержание токсичных и нетоксичных солей заметно выравнивается и степень засоления сменяется от среднезасоленной на слабозасоленную, химизм засоления переходит к содово-сульфатному. Тип почвы: $S-S S-G s$, ствол - постлитогенный, отдел - галоморфные почвы, тип солончак соровый.

На о. Ольхон катена, представленная 3 разрезами, расположена в межгорном понижении, около оз. Шара-Нур.

Разрез № 4 (ШН-1) заложен на средней части склона межгорного понижения у опушки леса. По всему профилю преобладает фракция крупного песка, которая составляет $45 \%$ в верхнем горизонте, в нижнем горизонте $-36 \%$. По гранулометрическому составу почва меняется с глубиной от супесчаной до среднесуглинистой. Реакция почвы изменяется от 7,2 до 9,4 ед. рН вниз по профилю. По степени засоления почва незасоленная. Сумма токсичных солей очень мала и варьируется по профилю от 0,006 до $0,02 \%$. Степень солонцеватости по всему профилю находится в пределах $-0,15-0,25 \%$. Тип почвы: $A Y-A E L-B E L B M-C$, отдел - текстурно-дифференцированные, тип - серые, подтип - типичные.

Разрез № 5 (ШН-2) заложен в приозерном понижении. Образцы отбирались через $10 \mathrm{~cm}$, так как почвенный профиль неоднородный. Верхние горизонты представлены средним суглинком, в нижних горизонтах идет облегчение гранулометрического состава до связного песка, а затем, в горизонтах ниже 50 см сменяется тяжелым суглинком. Причиной этому послужило, вероятнее всего, влияние волноприбойной деятельности озера. Величина $\mathrm{pH}$ почвы плавно увеличивается вниз по профилю от слабощелочной $(7,9)$ в верхнем горизонте до щелочной $(8,5)$ в нижних. Химизм засоления почвы содово-сульфатный, степень засоления вниз по профилю изменяется от среднезасоленной до незасоленной. Тип почвы: S[AU]-Gs-Cml,s,g, отдел - галоморфные, тип - солончаки темные сульфидный гидроморфный, подтип - омергеленные. 
Разрез № 6 (ШН-3) заложен на дне высохшего озера. Гранулометрический состав верхнего горизонта почвы относится к легкой глине, к нижнему горизонту облегчается до тяжелого суглинка. Сильнощелочная реакция среды уменьшается к нижним горизонтам и изменяется от 10,0 , до 8,6 ед. $\mathrm{pH}$. Распределение солей водной вытяжки и степень солонцеватости имеет максимальное значение в верхнем горизонте. Токсичные соли доминируют над нетоксичными по всему профилю. В данном разрезе наблюдается смена химизма засоления по катионному составу на калиево-натриевый, что указывает на особое образование и генезис оз. Шара-Нур. Тип почвы: $S-S S-S S g-G S$, отдел - галоморфные, тип - солончаки сульфидные гидроморфные, подтип - типичный.

В таблице представлены данные по степени засоления и химизму засоления почв по Базилевич-Панковой (Панкова, Базилевич, 1970).

Таблица

Химизм засоленных почв озер Гизги-Нур и Шара-Нур

\begin{tabular}{|c|c|c|c|c|c|c|}
\hline \multirow{2}{*}{$\begin{array}{c}\text { № } \\
\text { разреза }\end{array}$} & \multirow{2}{*}{$\begin{array}{c}\text { Глубина, } \\
\text { см }\end{array}$} & \multirow{2}{*}{$\begin{array}{c}\text { Сумма } \\
\text { токсичных } \\
\text { солей, \% }\end{array}$} & \multicolumn{2}{|c|}{$\begin{array}{c}\text { Классификация почвы по } \\
\text { Базилевич-Панковой (Панкова, 1970) }\end{array}$} & \multirow{2}{*}{$\begin{array}{c}\text { इнетокс, } \\
\%\end{array}$} & \multirow{2}{*}{$\begin{array}{c}\Sigma \text { токс, } \\
\%\end{array}$} \\
\hline & & & Степень засоления & $\begin{array}{c}\text { Химизм } \\
\text { засоления }\end{array}$ & & \\
\hline \multirow{6}{*}{$\begin{array}{c}1 \\
(\Gamma \mathrm{H}-1)\end{array}$} & $0-10$ & 0,02 & незасолённая & ГК-С-М-Кц & 62 & 38 \\
\hline & $10-20$ & 0,01 & незасолённая & ГК-С-М-Кц & 53 & 47 \\
\hline & $20-30$ & 0,01 & незасолённая & С-ГК-Кц-Н & 48 & 52 \\
\hline & $30-40$ & 0,02 & незасолённая & Х-ГК-Кц-Н & 25 & 75 \\
\hline & $40-50$ & 0,12 & слабозасоленная & ГК-Х-M-H & 44 & 56 \\
\hline & $50-60$ & 0,17 & слабозасоленная & C-X-M-H & 31 & 69 \\
\hline \multirow{7}{*}{$\begin{array}{c}2 \\
(\Gamma \mathrm{H}-2)\end{array}$} & $0-10$ & 0,01 & незасолённая & ГК-С-М-Кц & 31 & 69 \\
\hline & $10-20$ & 0,01 & незасолённая & С-ГК-М-Кц & 62 & 38 \\
\hline & $20-30$ & 0,13 & слабозасоленная & ГК-С-Кц-М & 56 & 44 \\
\hline & $30-40$ & 0,08 & слабозасоленная & ГК(+Кр)-C-M-H & 35 & 65 \\
\hline & $40-50$ & 0,10 & слабозасоленная & C- ГК(+Кр)-М-H & 26 & 74 \\
\hline & $50-60$ & 0,09 & слабозасоленная & $\Gamma К(+К р)-\mathrm{M}-\mathrm{H}$ & 17 & 83 \\
\hline & $60-70$ & 0,07 & слабозасоленная & ГК(+Кр)-M-H & 19 & 82 \\
\hline \multirow{6}{*}{$\begin{array}{c}3 \\
(\Gamma \mathrm{H}-3)\end{array}$} & $0-10$ & 2,50 & солончак & ГК(+Кр)-C-M-H & 3 & 97 \\
\hline & $10-20$ & 0,28 & среднезасоленная & ГК(+Кр)-С- & 15 & 85 \\
\hline & $20-30$ & 0,20 & слабозасоленная & Кц-Н & 23 & 77 \\
\hline & $30-40$ & 0,10 & слабозасоленная & ГК-С-Кц-Н & 27 & 73 \\
\hline & $40-50$ & 0,07 & слабозасоленная & ГК-С-Кц-Н & 62 & 38 \\
\hline & & & & ГК-С-Кц-Н & & \\
\hline \multirow{4}{*}{$\begin{array}{c}4 \\
(\amalg \mathrm{H}-1)\end{array}$} & $0-10$ & 0,024 & незасолённая & ГК-С-М-Кц & 42 & 58 \\
\hline & $10-20$ & 0,01 & незасолённая & С-ГК-М-Кц & 64 & 36 \\
\hline & $20-30$ & 0,01 & незасолённая & С-ГК-М-Кц & 70 & 30 \\
\hline & $30-40$ & 0,01 & незасолённая & С-ГК-М-Кц & 7 & 93 \\
\hline
\end{tabular}


Зверева Н. А., Хадеева Е. Р. Галогенез почв Приольхонья и о. Ольхон

\begin{tabular}{|c|c|c|c|c|c|c|}
\hline & $0-10$ & 0,38 & среднезасоленная & ГК-С-М-Кц & 44 & 56 \\
& $10-20$ & 0,11 & слабозасоленная & ГК-С-М-Кц & 50 & 50 \\
5 & $20-30$ & 0,01 & незасолённая & ГК-С-М-Кц & 70 & 30 \\
$($ ШН-2) & $30-40$ & 0,02 & незасолённая & ГК-С-М-Кц & 60 & 40 \\
& $40-50$ & 0,02 & незасолённая & ГК-С-М-Кц & 67 & 33 \\
& $50-60$ & 0,02 & незасолённая & ГК-С-М-Кц & 14 & 86 \\
& $60-70$ & 0,02 & незасолённая & ГК-С-М-Кц & 64 & 36 \\
& $70-80$ & 0,02 & незасолённая & ГК-С-М-Кц & 64 & 36 \\
\hline \multirow{5}{*}{6} & $0-10$ & 3,72 & солончак & С-ГК(+Кр)-К-Н & 15 & 85 \\
$($ ШН-3) & $10-20$ & 0,48 & сильнозасоленная & ГК-С-К-Н & 26 & 74 \\
& $20-30$ & 0,34 & сильнозасоленная & ГК-С-К-Н & 20 & 80 \\
& $30-40$ & 0,13 & слабозасоленная & ГК-С-К-Н & 28 & 72 \\
\hline
\end{tabular}

где ГК - гидрокарбонат; Кр - карбонат; С - сульфат; Х - хлорид; Кц - кальций; $\mathrm{M}-$ магний; К — калий; Н — натрий-ионы.

\section{Заключение}

Таким образом, в результате маршрутных и лабораторных работ выявлено, что основную часть территории около озер в Тажеранской степи занимают каштановые почвы и солончаки, вблизи оз. Шара-Нур - серые лесные почвы и солончаки. Почвы относятся к выпотному типу водного режима, где величина испарения превышает сумму атмосферных осадков. Их формирование связано преимущественно со следующими факторами: приуроченность к Байкальской рифтовой зоне; богатство солями почвообразующих пород; артезианский вынос солей; аридный климат с высокой солнечной радиацией; эоловый перенос материала; высыхание минеральных озер, в результате чего увеличиваются прибрежные территории засоленных почв; различный генезис озер Приольхонья и на Ольхоне.

Гранулометрический состав почв изменяется от супесчаного до среднесуглинистого, иногда со щебенкой и делювиальными отложениями. Во фракциях гранулометрического состава засоленных почв Приольхонья доминирует средний и мелкий песок, на Ольхоне - крупный, средний песок и ил. Реакция почвенного раствора варьирует от 7,2 до 10 ед. $\mathrm{pH}$, в то время как содержание легкорастворимых токсичных солей увеличивается с приближением к берегу, соответственно увеличивается и степень засоления - от незасоленных до солончаков. Максимальное содержание токсичных солей приходится на верхние горизонты солончаков.

В результате исследования трансект-катен можно сказать, что по химизму засоления почвы в Приольхонье относятся к содово-сульфатно магниевонатриевому, на о. Ольхон - сульфатно-содово калиево-натриевому.

Гумусовый горизонт засоленных почв отличается повышенным уплотнением за счет содержания обменных натрия и магния, которые обуславливают неблагоприятные физические и химические свойства. Почвы береговых линий и дна озер характеризуются высоким содержанием легкорастворимых токсичных солей. 


\section{Литература}

1. Агрофизические методы исследования почв / Отв. ред. д-р с.-х. наук С. И. Долгов; почв. институт им. В. В. Докучаева. Москва: Наука. 1966. - 259 с.

2. Агрохимические методы исследования почв / ред. Соколов А. В. Издательство: Наука, 1975. 656 с.

3. Аринушкина Е. В. Руководство по химическому анализу почв / Е. В. Аринушкина. М.: Изд-во МГУ, 1970. 488 с.

4. Атлас Байкала / гл. ред. Г. И. Галазий. М.: ФСГКР, 1993. 160с.

5. Атлас. Иркутская область: экологические условия развития. М. Иркутск, 2004. 90 с.

6. Воробьева Л. А. Теория и практика химического анализа почв / Л. А. Воробьева; под ред. Л. А. Воробьевой. М.: ГЕОС, 2006. 400 с.

7. Дзюба А. А. Распространение и химизм соленых озер Прибайкалья и Забайкалья / А. А. Дзюба, А. К. Тулохонов, Т. И. Абидуева, П. И. Гребнева // География и природные ресурсы. 2003. - № 4. С. 73-78.

8. Лопатин Д. В. Ярусное строение рельефа Приольхонья и острова Ольхон в геоморфологической структуре Западного Прибайкалья / Д. В. Лопатин, Т. М. Сковитина // Геоморфология. 2008. № 4. С. 83-91.

9. Лопатовская О. Г. Засоленные почвы Приольхонья и острова Ольхон: монография / О. Г. Лопатовская. Иркутск: Изд-во ИГУ, 2018. 205 с.

10. Максимова Е. Н., Лопатовская О. Г., Денисова Т. Д., Хадеева Е. Р. К характеристике микрофлоры засоленных почв о. Ольхон (Предбайкалье) // «Экологическая, промышленная и энергетическая безопасность. Севастополь, 2017 С. $829-831$.

11. Мартынов В. П. Почвы горного Прибайкалья / В. П. Мартынов. Улан-Удэ: Бурят. кн. изд-во, 1965. 165 с.

12. Николаев И. В. Почвы Иркутской области / И. В. Николаев. Иркутск, 1949. 404 с.

13. Панкова Е. И. Учет засоленных почв / Е. И. Панкова, Н. И. Базилевич // Методические рекомендации по мелиорации солонцов и учету засоленных почв. Колос М.: 1970. С. 1-32.

14. Почвенная карта Иркутской области. Масштаб 1: 1500000. М.: ГУГК, 1988.

15. Склярова О. А. Геохимия и генезис озер Приольхонья: Западное Прибайкалье: дис. ... канд. геол.-минерал. наук: 25.00.09. М.: РГБ, 2004. 121с.

16. Черноусенко Г. И. Распространение, химизм и генезис засоленных почв Предбайкалья / Г. И. Черноусенко, И. А. Ямнова, О. Г. Лопатовская // География и природные ресурсы. 2006. № 2. С. 84-92.

\section{HALOGENESIS OF SOILS IN THE PRIOLKHONYE AND ISLAND OLKHON}

\section{N. A. Zvereva, E. R. Khadeeva}

Nadezhda A. Zvereva

Lead Engineer,

Institute of Geography named V.B. Sochava SD RAS

Russia, Irkutsk, 664033, Ulan-Batorskaya st., 1

E-mail: koffffein@mail.ru,war_ker@mail.ru 


\section{Ekaterina R. Khadeeva}

Lead Engineer,

Institute of Geography named V.B. Sochava SB RAS

Russia, Irkutsk, 664033, Ulan-Batorskaya st., 1

E-mail: war_ker@mail.ru

In Priolkhonye and on the Ol'khon Island, in the coastal part of saline lakes are formed intrazonal soils, such as salt marshes, containing in the profile easily soluble salts in quantities toxic for plants. The salt marshes and other saline soils are an interesting object for research in terms of classification, the influence of cryogenic and other factors of formation, as well as halogenesis. One of the factors of halogenesis is the salt accumulation during the evaporation of capillary solutions of groundwater on the soil surface. As a result of climate aridization, salt lakes dry out and the areas of saline soils increase. The process of halogenesis and the salt accumulation still do not find unity of views due to the lack of attention to the geosystem approach.

Keywords: halogenesis, saline soils, Priol'khonye, Ol'khon Island, karst lakes, lakes of tectonic origin, climate aridization, toxic salts. 